\title{
Multi-Marker Study of Dreissena polymorpha Populations from Hydropower Plant Reservoir and Natural Lake in Latvia
}

\author{
Lesya Gnatyshyna ${ }^{1,3}$, Vira Khoma ${ }^{1}$, Oksana Horyn ${ }^{1}$, Davis Ozolingš ${ }^{2}$, Agnia Skuja ${ }^{2}$, \\ Ilga Kokorite ${ }^{2}$, Valery Rodinov ${ }^{2}$, Viktoria Martyniuk ${ }^{1}$, Gunta Sprinǵge ${ }^{2}$, \\ Oksana Stoliar ${ }^{1 *}$ (i)
}

\author{
${ }^{1}$ Volodymyr Hnatiuk Ternopil National Pedagogical University, Kryvonosa Str 2, 46027, Ternopil, Ukraine \\ ${ }^{2}$ University of Latvia, Institute of Biology, Miera Str. 3, Salaspils, LV 2169, Latvia \\ ${ }^{3}$ I.Ya. Horbachevsky Ternopil State Medical University, Ternopil, Ukraine, 46001
}

\section{Article History}

Received 08 January 2019

Accepted 28 October 2019

First Online 05 November 2019

\section{Corresponding Author \\ Tel.: +380965956904 \\ E-mail: \\ Oksana.Stolyar@tnpu.edu.ua}

\section{Keywords}

Zebra mussel

Hydro power plant

Oxidative stress

Metallothionein

Apoptosis

\begin{abstract}
Hydropower plants (HPPs) are equipped with reservoirs that can accumulate the toxic effluents and disturb the water flow of rivers. The aim of this study was to evaluate the biochemical responses of zebra mussel Dreissena polymorpha inhabiting the reservoir of Riga HPP in comparison with the responses of the mussels from the natural lake Kanieris in Latvia. In the reservoir mussels, high Mn-SOD activity and low level of the lipid peroxidation (production of TBARS) in the soft tissues suggested an elevated antioxidant activity. Compared to the lake specimens, the reservoir mussels had low levels of RI GSH while their lactate/pyruvate ratio was 1.4 times higher. In the mussels from the reservoir, high level of protein carbonilation products, as well as lowered caspase-3 and extralysosomal cathepsin D activities (by 1.4 and 1.6 times respectively, compared to the lake specimens) indicated delayed apoptosis. Catalase and glutathione $S$-transferase activities and metallothionein concentration were similar in both groups. Vitellogenin-like proteins (detected as the alkali-labile phosphates) and cholinesterase levels were higher in the mussels from the reservoir. We chose the indexes of the redox capacity as the most suitable markers of the environmental impact on this organism.
\end{abstract}

\section{Introduction}

Hydropower is the most important and most economical of renewable energy sources for electricity generation; its importance in the future is expected to increase (Kaunda, Kimambo, \& Nielsen, 2012; Atilgan \& Azapagic, 2016). Hydropower could prove especially valuable in the context of climate change due to its low carbon footprint and high power generation efficiency. A comparison of different Hydroelectric Power Plants (HPPs) demonstrated that environmental impacts from large reservoirs were overall lower than that of small reservoirs and run-of-river hydropower (Atilgan \& Azapagic, 2016). Additionally, large reservoirs could be utilised for other purposes. For example, the reservoir of Riga HPP is also the source of drinking water for Riga
City. On the other hand, these artifical reservoirs could accumulate toxic effluents, alter temperature regime and cause degradation of aquatic ecosystems (Faria et al., 2010; Warner, 2012; Fu, Wang, Xu, Yan, \& Li, 2014; Rambo et al., 2017). The Daugava River alone accounts for approximately $60 \%$ of the total riverine load to the Gulf of Riga (Laznik, Stålnacke, Grimvall, \& Wittgren, 1999). Therefore, the environmental impact of HPP reservoirs needs to be evaluated.

The majority of ecotoxic studies of the impact of HPPs is mostly focused on the accumulation of toxic metals, persistent organic substances (Lebedynets, Sprynskyy, Kowalkowski, \& Buszewski, 2004; Zhu et al., 2012) and genotoxicity caused by the sediment (Rambo et al., 2017). Data on bioindication of ecotoxicity of Riga reservoir is relatively limited. Some information is 
available on riverine contribution to the eutrophication of the Gulf of Riga and its dependence on the river input (Stålnacke et al., 1999; Agrell et al., 2001). Biochemical markers in the aquatic animals in this area were not evaluated (Agrell et al., 2001).

The selection of relevant bioindicative organisms is a crucial point for an ecotoxicity study (Hook, Gallagher, \& Batley, 2014). Bivalve molluscs are excellent indicator organisms to assess the effects of environmental stressors on aquatic ecosystems and human exposure since they have sedentary nature, filter-feeding behavior, ability to accumulate pollutants and sensitivity to environmental temperature (Viarengo, Lowe, Bolognesi, Fabbri, \& Koehler, 2007; Dailianis, 2010). In particular, the invasive bivalve zebra mussel is a popular indicator organism due to its ability to accumulate toxic metals and persistent organic substances (Kwan, Chan, \& de Lafontaine, 2003; Quinn et al., 2004; Contardo-Jara \& Wiegand, 2008; Faria et al., 2010; Riva, Parolini, Binelli, \& Provini, 2010; Lepom, Irmer, \& Wellmitz, 2012). Stress biomarkers can be used to evaluate the health status affected by both contaminants and nonchemical stressors (Lushchak, 2011; Hook et al., 2014; Kerambrun et al., 2016; Potet et al., 2018a,b). In mussel, the development of a stress syndrome along the pollution gradient was demonstrated using a novel species-specific microarray, both in terms of numbers of expressed genes and level of gene response (Dondero et al., 2006). However, since zebra mussel is an invasive species, it has been debated whether its biomarker responses appropriately reflect the environmental impact compare to the native species (Crooks, Chang, \& Ruiz, 2011).
The main objective of this study was to evaluate the environmental impacts in the reservoir of Riga HPP using zebra mussel as a sentinel organism. For this purpose, we aimed to study the responses of stress and toxicity in the populations inhabiting both the artificial Riga reservoir and a natural lake Kanieris in Latvia, which is presumably clean. We selected the widely utilized biochemical markers in molluscs, namely the indices of oxidative stress, metabolic depression, metallothionein levels (as the marker of contamination by toxic metals), and cholinesterase levels (as the marker of organophosphate and thiocarbamate toxicity). Vitellogenin-like proteins, determined as alkali-labile proteins (ALP), were included as components that supply gametogenesis with phosphates and zinc. The indices of apoptosis, caspase- 3 and cathepsin D were also evaluated. To the best of our knowledge, such approach was applied for the first time for the evaluation of the ecosystem of Riga reservoir.

\section{Materials and Methods}

\section{Chemicals}

All chemicals were purchased from Sigma Aldrich (St. Louis, USA) and SinbiaS (Ukraine) and were of the Reagent grade or higher.

\section{Sampling}

Zebra mussels, Dreissena polymorpha (Pallas, 1771), were collected in Autumn (September) 2017 in the north-western part of the Reservoir of Riga HPP

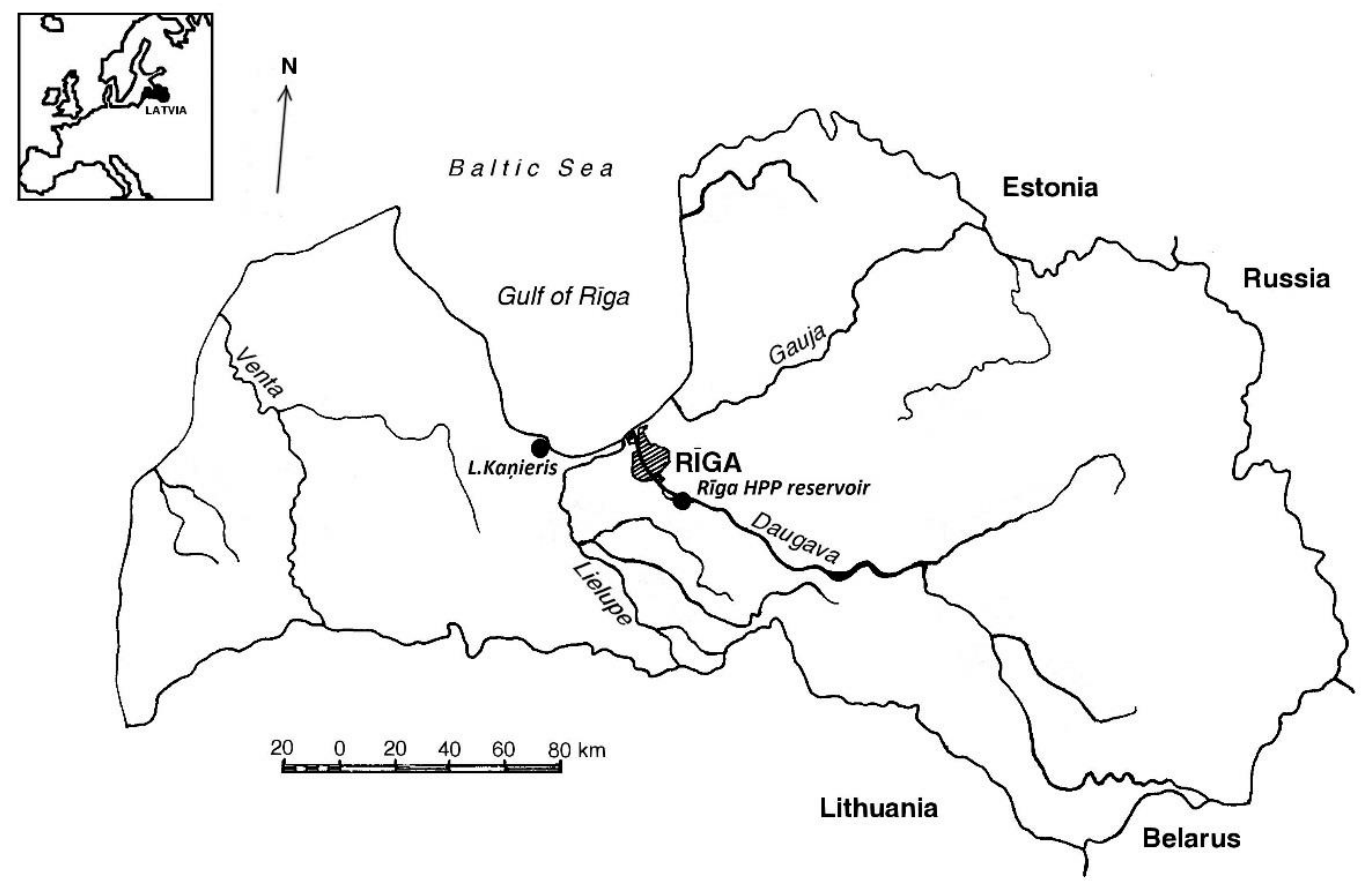

Figure 1. Localization of the sampling sites in Latvian area: Lake Kanieris (57०00'04"N 23029'20"E) and Reservoir of Riga HPP $\left(56^{\circ} 49^{\prime} 59^{\prime \prime} \mathrm{N} 24^{\circ} 19^{\prime} 59^{\prime \prime} \mathrm{E}\right)$. Note. $(\bullet)$ indicate the location of sampling sites 
$\left(56^{\circ} 49^{\prime} 59^{\prime \prime} \mathrm{N} 24^{\circ} 19^{\prime} 59^{\prime \prime} \mathrm{E}\right)$ and the natural lake Kanieris $\left(57^{\circ} 00^{\prime} 04^{\prime \prime} \mathrm{N} 23^{\circ} 29^{\prime} 20^{\prime \prime} \mathrm{E}\right)$. The Riga reservoir is situated on the cross-border River Daugava and is the last one in the cascade of reservoirs on the river (Figure 1). Lake Kanieris is a shallow lagoon clearwater macrophyte lake. It has been a protected site since 1964 as an important place for birds, and is also a part of Kemeri National Park (1997) (https://www.meteo.lv).

The samplings were carried out simultaneously in both sites. The individuals were transported to the cooled boxes filled with lake water and constantly aerated. In each group, the specimens with the average weight 2-4 $\mathrm{g}$ and the shell length between 2.4 and 3.0 $\mathrm{cm}$ were selected for the purposes of the present study. The molluscs were dissected on ice. For all biochemical traits, total soft tissue from 5 molluscs were combined in each sample. Totally, six such combined sets were used for each biochemical analysis in each experimental group. The samples were stored at $-40^{\circ} \mathrm{C}$ until further analysis. The soluble extracted protein concentration in the samples was measured by the method of Lowry, Rosebrough, Farr, and Randall (1951), using bovine serum albumin as the protein standard. The absorbance values were measured on an UV/Vis spectrophotometer "Lomo-56" (Russian Federation).

\section{Oxidative Stress Indices}

For the oxidative stress indices in the soluble fraction of homogenate, the samples of tissue were homogenized $(1 / 10 \mathrm{w} / \mathrm{v})$ in $0.1 \mathrm{M}$ phosphate buffer, $\mathrm{pH}$ 7.4, containing $100 \mathrm{mM} \mathrm{KCl}$ and $1 \mathrm{mM}$ EDTA, as well as $0.1 \mathrm{mM}$ phenylmethylsulfonyl fluoride for proteolysis inhibition. Homogenates were centrifuged for $10 \mathrm{~min}$ at $6,000 \times g$.

Superoxide dismutase (SOD, EC 1.15.1.1) activity was measured according to the method of Beauchamp and Fridovich (1971) based on the aerobic reduction of nitroblue tetrazolium at $535 \mathrm{~nm}$ by superoxide radicals in the darkness and expressed as units. $\mathrm{mg}^{-1}$ of soluble protein. In order to assess Mn-SOD activity, the supernatant was preincubated for $60 \mathrm{~min}$ at $0{ }^{\circ} \mathrm{C}$ in the presence of $5 \mathrm{mM} \mathrm{KCN}$, which produced total inhibition of $\mathrm{Cu}, \mathrm{Zn}-\mathrm{SOD}$. The latter activity was calculated as the difference between the activities in the absence and the presence of KCN. A unit of SOD activity was defined as the amount of protein causing $50 \%$ inhibition of NBT reduction rate.

Catalase (CAT, EC 1.11.1.6) activity was measured by monitoring the decomposition of $10 \mathrm{mM} \mathrm{H}_{2} \mathrm{O}_{2}$ according to Aebi (1974) at $240 \mathrm{~nm}\left(\varepsilon=40 \mathrm{M}^{-1} \cdot \mathrm{cm}^{-1}\right)$ in a

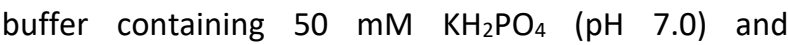
approximately $150 \mu \mathrm{g}$ of protein. The results were related to the soluble protein.

Glutathione S-transferase (GST, EC 2.5.1.18) activity was measured using 1-chloro-2,4dinitrobenzene as the substrate (Habig, Pabst, \& Jakoby, 1974). The GST activity was expressed as $\mathrm{nmol} \cdot \mathrm{min}^{-1} \cdot \mathrm{mg}$ ${ }^{1}$ soluble protein.
Lipid peroxidation (LPO) was determined by the production of thiobarbituric acid-reactive substances (TBARS) (Ohkawa, Onishi, \& Yagi, K., 1979). A molar extinction coefficient of $1.56 \cdot 10^{5} \mathrm{M}^{-1} \cdot \mathrm{cm}^{-1}$ was used.

Protein carbonyl (PC) content, as an index of protein oxidation, was measured by the reaction with 2 , 4-dinitrophenylhydazine (DNPH) (Reznick \& Packer, 1994). The differences in absorbance between the DNPH- and the $\mathrm{HCl}$-treated samples were determined by spectrophotometry at $375 \mathrm{~nm}$, and the amount of PC was calculated by using a molar extinction coefficient of $2.2 \cdot 10^{4} \mathrm{M}^{-1} \cdot \mathrm{cm}^{-1}$. The results were expressed as $\mathrm{nmol}$ PC.per $g$ of fresh weight (FW).

\section{Redox balance and metabolic characteristics}

Total glutathione (GSHt) and oxidized glutathione (GSSG) concentrations were quantified in the $1 / 10 \mathrm{w} / \mathrm{v}$ homogenate of tissue by the glutathione reductase recycling assay (Anderson, 1985). To estimate the GSSG level, the protein free sample was treated with 2vinylpyridine prior to the assay at $2 \%$ final concentration. The rate of 5-thionitrobenzoic acid formation from 5,5-dithiobis-2-nitrobenzoate (DTNB) was detected spectrophotometrically at $412 \mathrm{~nm}$. Standards were prepared from reduced glutathione (GSH) and GSSG, and concentrations were expressed as $\mathrm{nmol} / \mathrm{g}$ wet weight. Redox index of glutathione (RI GSH) was calculated as the ratio of concentrations of GSH/GSSG by dividing the difference between the GSHt and GSSG concentrations by the concentration of GSSG: (GSHt-2GSSG)/2GSSG.

The lactate and pyruvate levels were determined spectrophotometrically. Lactate was assayed by the NAD-dependent enzymatic oxidation of lactate to pyruvate by D-lactate dehydrogenase (D-LDH) (EC 1.1.1.28) from Lactobacillus leichmannii. Pyruvate was measured by conversion of pyruvate acid to D-lactate by $\mathrm{D}-\mathrm{LDH}$ in the presence of NADH. The changes in NADH concentration were monitored by absorbance at $340 \mathrm{~nm}$ using the molar extinction coefficient of $6.22 \cdot 10^{6} \mathrm{M}^{-1} \mathrm{~cm}^{-}$ ${ }^{1}$ (Gawehn, 1988; Lamprecht \& Heinz, 1988). The ratio of the concentrations of lactate/pyruvate was calculated.

The concentration of the alkali-labile phosphates (ALP) related to the lipophosphoprotein vitellogenin was measured in the $10 \mathrm{w} / \mathrm{v}$ homogenate of gonads in $25 \mathrm{mM}$ Hepes- $\mathrm{NaOH}$ buffer, $\mathrm{pH}$ 7.4, containing $125 \mathrm{mM}$ $\mathrm{NaCl}, 1 \mathrm{mM}$ dithiothreitol, and $1 \mathrm{mM}$ EDTA according to the protocol of Gagné et al. (2003). The labile phosphates were quantified by the phosphomolybdenum assay. ALP levels were given as $\mu \mathrm{mol}$ phosphates $\mathrm{mg}^{-1}$ soluble protein.

\section{Markers of toxicity}

The concentration of metallothioneins (MTs) was assessed in the $1 / 10 \mathrm{w} / \mathrm{v}$ homogenates by the concentrations of thiols using DTNB reduction method (Viarengo, Ponzano, Dondero, \& Fabbri, 1997) after the ethanol/chloroform extraction and calculated assuming 
the relationship: $1 \mathrm{~mol}$ of MTs corresponds to $20 \mathrm{~mol}$ of GSH and expressed as $\mu \mathrm{g}$ of MTs per $\mathrm{g}$ of FW.

The cholinesterase (ChE, EC 3.1.1.7) activity was determined according to the colorimetric method of Ellman, Courtney, Andres, and Featherstone (1961) at $25{ }^{\circ} \mathrm{C}$. The reaction mixture contained $3.0 \mathrm{ml} 0.1 \mathrm{M} \mathrm{Na}$ phosphate buffer, pH 8.0, $0.1 \mathrm{~mL} 0.01 \mathrm{M}$ DTNB in $0.1 \mathrm{M}$ Na-phosphate buffer $(\mathrm{pH} 7.0,15 \mathrm{mg}$ sodium bicarbonate per $10 \mathrm{~mL}$ of solution) and an aliquot of supernatant $(0.02 \mathrm{~mL})$. The reaction was initiated by addition of 0.04 $\mathrm{mL} 0.075 \mathrm{M}$ acetylcholine iodide to the reaction mixture. The rate of thionitrobenzoate production evaluated during $5 \mathrm{~min}$ at $412 \mathrm{~nm}$ was used to estimate hydrolysis. The enzyme activity was calculated using a molar extinction coefficient of $13.6 \cdot 10^{3} \mathrm{M}^{-1} \cdot \mathrm{cm}^{-1}$ and referred to the soluble protein content.

\section{Assays of apoptotic enzymes activities}

The cathepsin D (EC 3.4.23.5) activity was determined with $1 \%$ hemoglobin as substrate as described by Dingle, Barrett, and Weston (1971). Cathepsin D acts on acid denatured hemoglobin resulting in a soluble colored complex which can be read spectrophotometrically at $280 \mathrm{~nm}$. The free cathepsin D activity (out of lysosomes) was assessed in the homogenate without detergent addition, whereas the total cathepsin D activity was measured after the enzyme release by Triton X100 treatment. The activities were determined using a standard curve with thyrosine, and expressed as nmol tyrosine $\mathrm{min}^{-1} \mathrm{mg}^{-1}$ of soluble protein.

The caspase-3-like activity was assayed colorimetrically in $25 \% \mathrm{w} / \mathrm{v}$ homogenate of tissue based on the hydrolysis of peptide acetyl-Asp-Glu-Val-Asp pnitroanilide (Ac-DEVD-pNA) by caspase-3 that produces a colored product p-nitroaniline (pNA). pNA was detected at $405 \mathrm{~nm}\left(\varepsilon_{\mathrm{mm}}=10.5 \mathrm{mM}^{-1} \cdot \mathrm{cm}^{-1}\right)$ (Bonomini, Dottori, Amoroso, Arduini, \& Sirolli, 2004). The activity of caspase-3 was expressed as nmol pNA min-1 $\mathrm{mg}^{-1}$ of soluble protein.

\section{Statistical analysis}

The data are presented as means \pm standard deviation (SD) unless indicated otherwise. Data were tested for normality and homogeneity of variance by using Kolmogorov-Smirnoff and Levene's tests, respectively. Whenever possible, data were normalized by Box-Cox common transforming method. For the data that were not normally distributed even after the transformation, non-parametric tests (Kruskall-Wallis ANOVA and Mann-Whitney U-test) were performed. Pearson's correlation test for the pairs of variables was performed at 0.05 level of significance. All statistical calculations were performed with Statistica v. 10.0 and Excel for Windows-2010. Differences were considered significant if the probability of Type I error was less than 0.05 .

\section{Results}

\section{Oxidative stress response}

The analysis of antioxidant enzymes determined that total SOD activity was similar in the mussels from both sites (Figure 2A). However, the distribution of activity among $\mathrm{Cu}, \mathrm{Zn}$ - and $\mathrm{Mn}$-forms of SOD was very different. In the samples from the natural lake, each form accounted for the similar proportion of the activity, while in the mussels from the reservoir Mn-SOD activity was dominant ( $\approx 93.6 \%$ of total activity). The CAT and GST activities did not differ significantly between the specimens from both sites (Figure 2B). The level of LPO was higher (TBARS, by $38.5 \%$ ) in the specimens from the natural lake (Figure 2C). In contrast, protein carbonyl level was lower in these molluscs by $25.4 \%$ (Figure $2 \mathrm{C}$ ).

\section{Cellular low weight thiols}

The metallothionein had similar concentrations in both groups (Figure 3A). However, the levels of GSH, GSSG and the RI GSH were substantially different, with higher values for all of them in the mussels from the natural lake, by $1.57,1.18$ and 1.32 times respectively (Figure 3B,C,D).

\section{Markers of metabolic response}

The level of lactate did not differ between both groups, whereas pyruvate level was 1.54 times lower in the mussels from the reservoir, resulting in a significantly higher lactate/pyruvate ratio (by 1.4 times) in reservoir mussels (Figure $4 A, B, C$ ). The level of ALP was higher in the mussels from the reservoir (Figure 4D).

\section{Markers of toxicity}

The intensity of apoptosis, as determined based on the activity of caspase-3, was 1.43 times higher in the molluscs from the natural lake (Figure 5B). The total cathepsin $D$ activity was of the same magnitude in the mussels from both sites, however, the distribution of this activity between the lysosomes and a soluble fraction was different, with 1.62 times higher efflux in the mussels from the natural lake (Figure 5A). The evaluation of ChE activity also detected differences between the mussels from both sites, with values measured in the specimens from the natural lake 1.36 times lower compared to the reservoir (Figure 5B).

\section{Correlation Analysis}

The correlation analysis (Table 1) shows the highest number of associations for pyruvate (six positive, two negative), GSH (five positives and one negative), and GSSG (two positive and three negative). For metallothionein, the correlations were absent. 

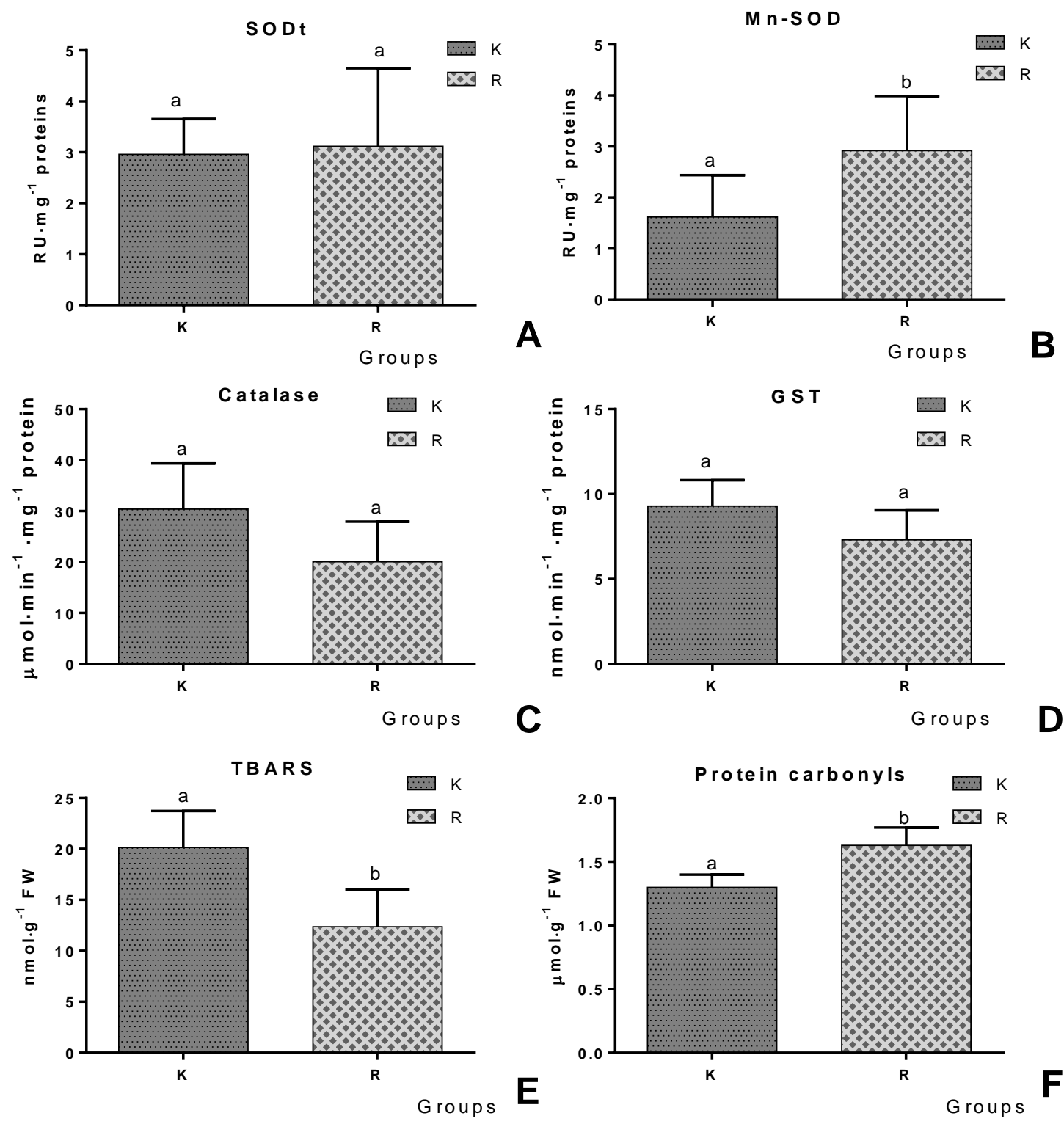

Figure 2. The indices of oxidative stress in the soft tissues of zebra mussel from the reference site $(K)$ and Riga reservoir $(R)$. Data for A: total SODt activity; B: Mn-SOD activity; C: catalase activity; D: GST activity; E: TBARS level; F: protein carbonyls level are presented as mean $\pm S D(n=6)$. For each endpoint/parameter, different letters above the bars indicate significant differences $(P<0.05)$

\section{Discussion}

The Daugava river in its lower portion collects the effluent from a large area. A sizable proportion of the pollution load comes from transboundary sources in Russia and Belarus. It is estimated that $37 \%$ of total nitrogen load and $46 \%$ of total phosphorus load entering the Baltic Sea via Latvian territory originate from transboundary sources (HELCOM, 2018). Locally, Riga City as well as agricultural lands are likely contributors to the PCBs and DDTs pollution in the reservoir (Agrell et al., 2001). A recent study (Ikkere, Perkons, Sire, Pugajeva, \& Bartkevics, 2018) that had measured persistent organic pollutants and emerging pollutants in freshwater molluscs in Latvia found high concentrations of ibuprofene and polybrominated diphenyl ethers in the samples from Riga HPP contained. Nevertheless, the level of pollution in the lower portions of the Daugava was estimated as comparatively low (Strode, Jansons, Purina, Balode, \& Berezina, 2017).

Previous studies utilizing biochemical markers in aquatic animals to assess environmental quality of the aquatic ecosystems in Latvia were mainly focused on the Gulf of Riga (e.g., Putna et al., 2014). There was evidence that the river Daugava pollution affects benthic animals in the Gulf of Riga, since the highest values of Integrated Biomarker Response (IBR index) were found in the Macoma balthica sampled near the mouth of the river (Barda, Purina, Rimsa, \& Balode, 2014). In a comparative study of biomarkers in the Atlantic salmon Salmo salar 

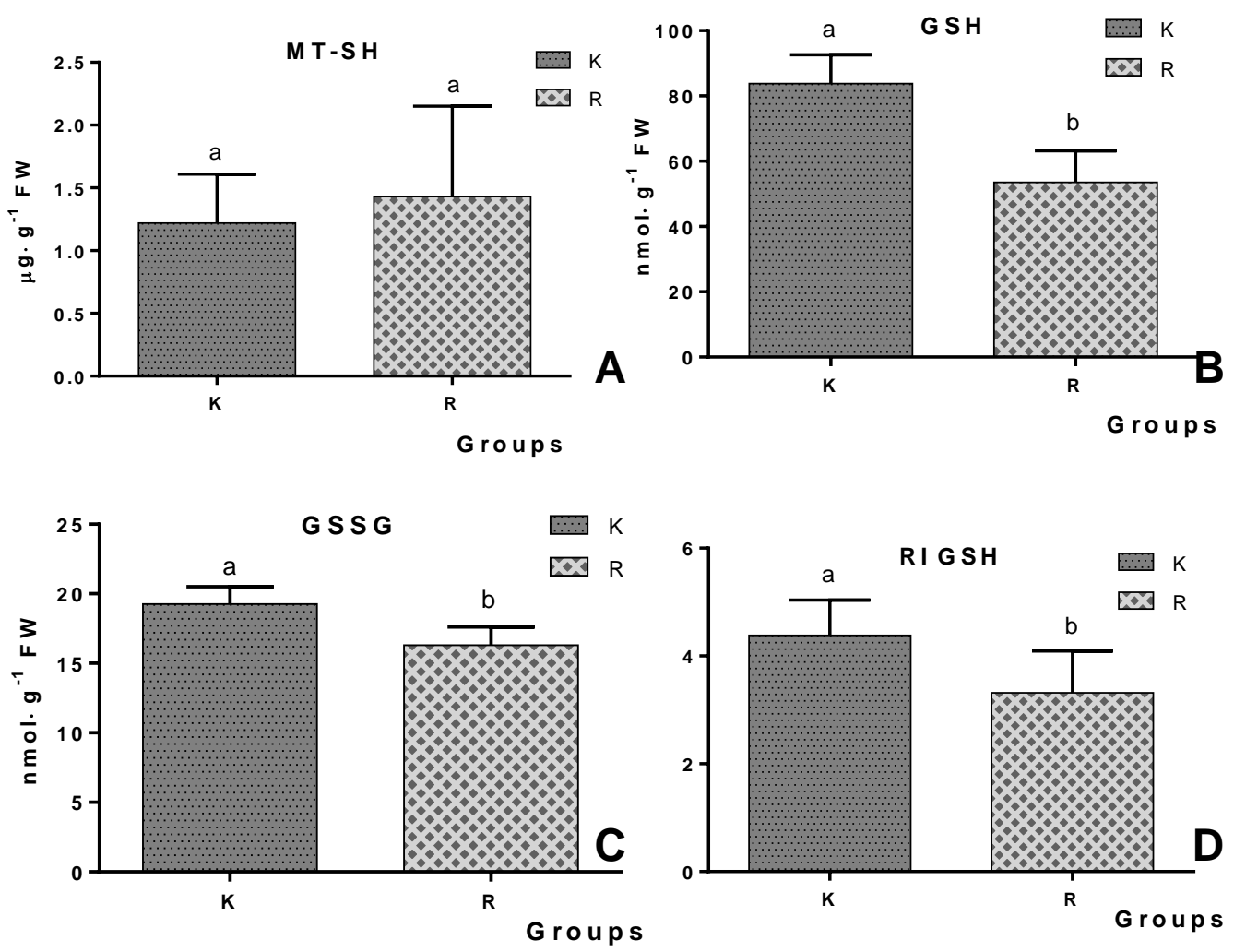

Figure 3. Low weight thiols in the soft tissues of zebra mussel from the reference site $(K)$ and Riga reservoir $(R)$. Data for A: metallothioneins; B: GSH; C: GSSG; D: RI GSH, presented as mean \pm SD $(n=6)$. Different letters above the bars indicates that the values differ significantlv $(P<0.05)$.

in the Baltic Sea, the specimens originating from the Daugava and Gauja rivers had lower catalase activity compared to the other stocks (Vuori, Kiljunen, Kanerva, Koljonen, \& Nikinmaa, 2012).

In this study we focused on the stress and toxicity responses of a recognized indicator species, the invasive bivalve mollusc zebra mussel. The results reflect substantial differences between the two sampled populations. Most notable differences were related to antioxidant activity and redox level. High Mn-SOD activity in the mussels from the reservoir indicates activation of mitochondrial oxygen-related processes (Santovito, Piccinni, Cassini, Irato, \& Albergoni, 2005; Wang, Yuan, Wu, Liu, \& Zhao, 2013). Low TBARS level corroborates activation of antioxidant response in the molluscs from the reservoir. On the other hand, protein carbonylation suggests protein damage and aging. This accumulation of protein damage can be the consequence of depressed apoptotic activity (attested by the low caspase-3 activity). Lysosomal cathepsin D activity supports proteoglican breakdown and amino acid utilization for energy metabolism (Dingle et al., 1971; Lamarre et al., 2016; Benes, Vetvicka, \& Fusek, 2008). This strategy of resistance to apoptosis is known to assist in long-term survival in some species, particularly invertebrates (Menze, Fortner, Nag, \& Hand, 2010; Portt, Norman, Clapp, Greenwood, \& Greenwood, 2011).
While HPP reservoir molluscs also had high lactate/pyruvate ratio, it was not caused by the upregulation of anaerobic conversion of glucose to lactate, given that lactate levels were similar in both populations (Figure 4). Thus, this group did not demonstrate the shift to anaerobiosis, a typical adaptation to a toxic environment or extreme temperature (de Zwaan \& Eertman, 1996). In contrast, the comparatively low pyruvate level in the reservoir mussels appears to indicate a higher rate of metabolic source utilization by the mitochondria (Gray, Tompkins, \& Taylor, 2014), as confirmed by the elevated Mn-SOD level. The resulting high lactate/pyruvate ratio in the reservoir group favors the high redox potential of $\mathrm{NADH}$, supplying metabolic activity. The elevated level of ALP in the HPP reservoir mussels shows that the rate phosphates and $\mathrm{Zn}$ supply to gametogenesis is high (Gagné \& André, 2011). These preferential pathways demonstrate that reservoir mussels have developed a tolerance strategy of biochemical adaptation (Somero, 2004). On the other hand, in the natural lake mussels, high TBARS levels suggested oxidative degradation of lipids. Simultaneous cathepsin D efflux from the lysosomes can weaken cathepsin D activity in the lysosomes and stimulate autophagy (Bursch et al., 2008; Man \& Kanneganti, 2016). High caspase-3 activity also indicates intensified apoptosis removing injured cells (Romero et al., 2011). 

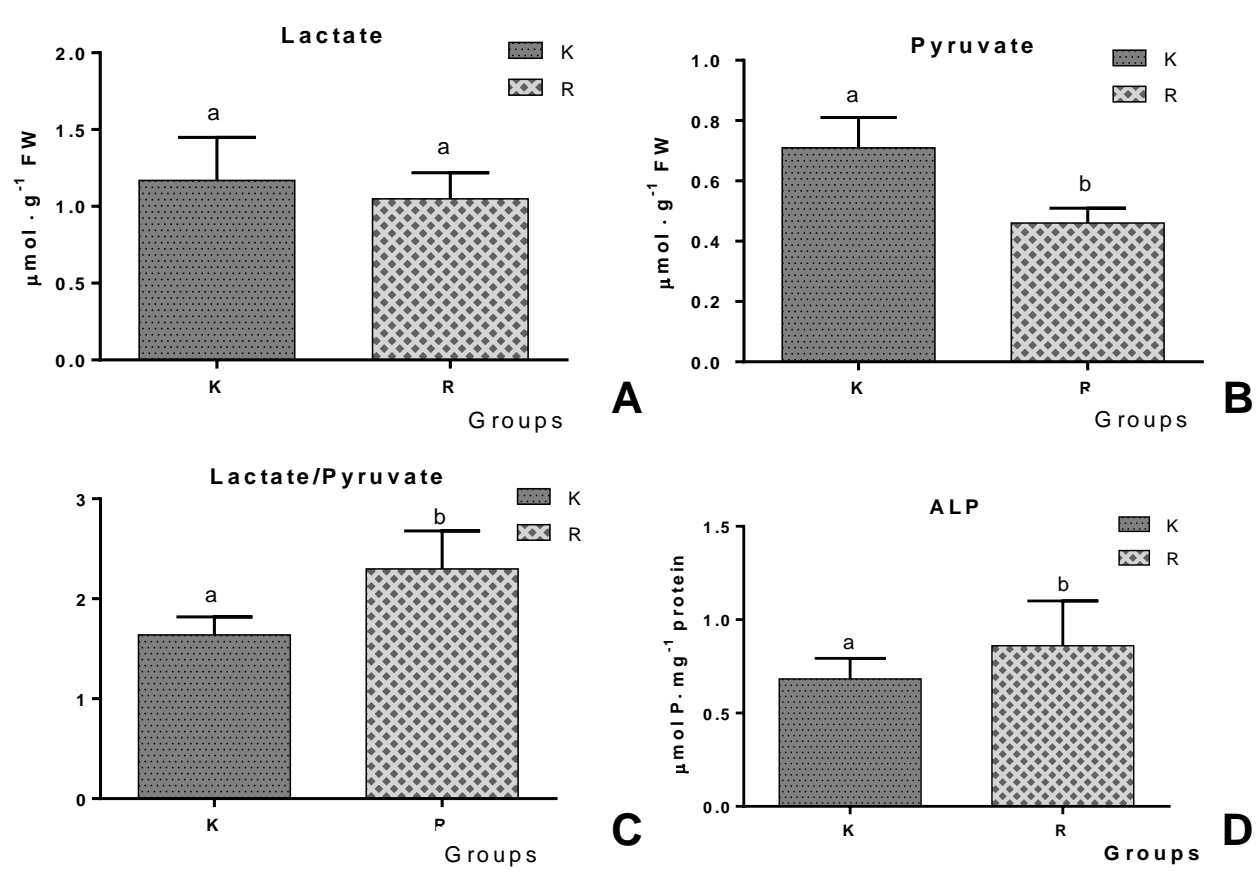

Figure 4. The metabolic characteristics in the soft tissues of zebra mussel from the reference site $(K)$ and Riga reservoir (R). Data for A: lactate; B: pyruvate; C: lactate/pyruvate concentration ratio, D: alkali-labile proteins; presented as mean \pm SD $(n=6)$. For each endpoint/parameter, different letters above the bars indicate significant differences $(P<0.05)$.
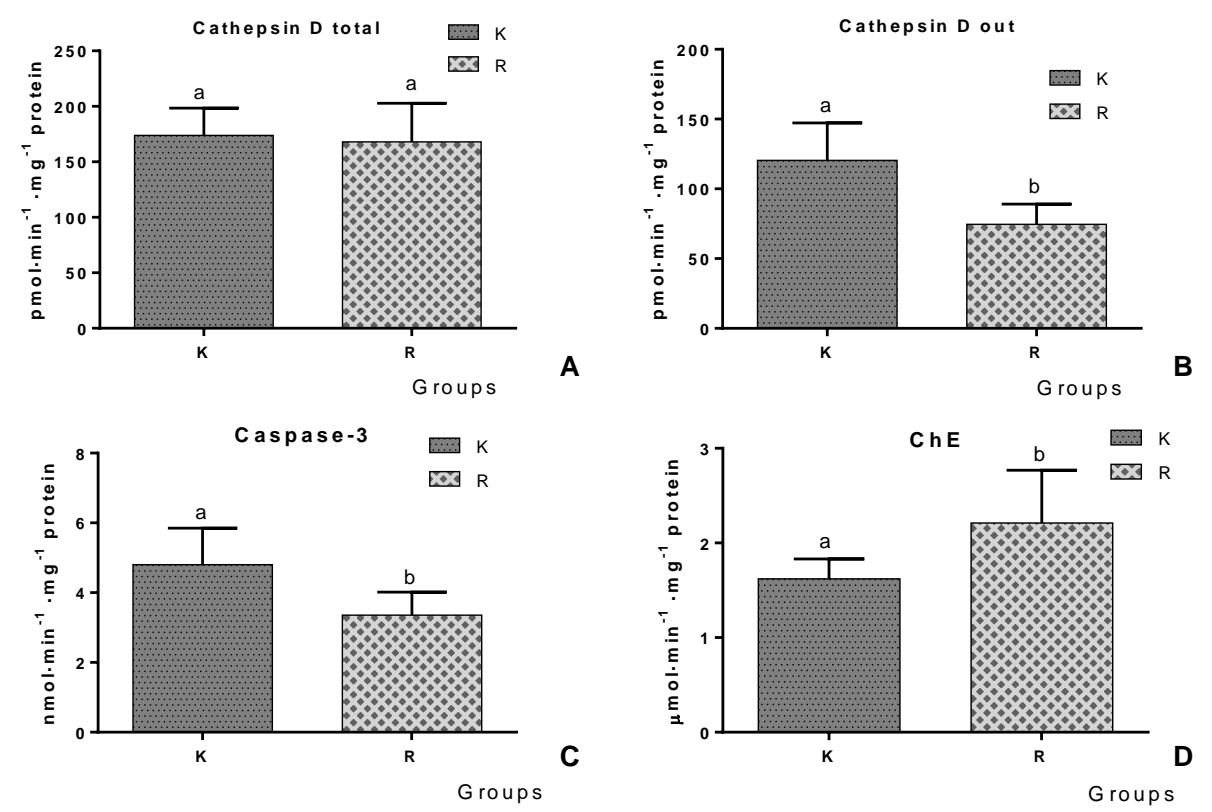

Figure 5. The indices of toxicity in the soft tissues of zebra mussel from the reference site (K) and Riga reservoir (R). Data for A: total cathepsine D activity; B: lysosome-out cathepsine D activity; C: caspase-3 activity; D: cholinesterase activity, presented as mean \pm SD $(n=6)$. Different letters above the bars indicates that the values differ significantly $(P<0.05)$.

At the same time, the natural lake mussels demonstrated high GSH and GSSG levels and the redox state of GSH. Moreover, of all studied markers, the GSHrelated indices showed the highest difference between the two populations (Figure 3). GSH provides the first line of defence as a ROS scavenger (Circu \& Aw, 2008). The GSH level differences were the main distinguishing criteria for gastropods from a lake near the place of Chernobyl nuclear disaster (Gnatyshyna et al., 2012) and zebra mussels, transplanted to different sites for 14 120 days (Falfushynska, Gnatyshyna, Stoliar, DedourgeGeffard, \& Geffard, 2010).

In our study two pairs of redox suppliers, RI GSH and lactate/pyruvate were highly intercorrelated (Table 1) attesting the redox balance as an important link in the chain of mussel's adaptive responses (Dailianis, 2010; Hellou, Ross, \& Moon, 2012). The level of GSH correlated with the caspase- 3 activity (Table 1 ). The activity and 
Table 1. The Pearson coefficient of correlation $r$ for the studied indices in the $D$. polymorpha from two populations; ${ }^{*}$, correlation significant $(P<0.05)$ at $r>0.576$

\begin{tabular}{|c|c|c|c|c|c|c|c|c|c|c|c|c|c|c|c|c|c|c|c|}
\hline Indices & GSH & GSSG & RI GSH & GST & SODt & Mn-SOD & CAT & TBARS & $\mathrm{PC}$ & LDH & Lac & Pyr & Lac/Pyr & Cas-3 & CatDt & CatDe & ALP & ChE & Prot \\
\hline MT & -0.276 & -0.171 & -0.243 & -0.169 & 0.208 & 0.203 & 0.044 & 0.067 & 0.196 & 0.240 & 0.063 & 0.140 & -0.145 & 0.000 & -0.022 & 0.043 & -0.124 & -0.067 & -0.096 \\
\hline GSH & & 0.532 & $0.903 *$ & $0.686 *$ & 0.010 & -0.398 & 0.366 & 0.543 & $-0.698 *$ & 0.068 & 0.466 & $0.783^{*}$ & -0.498 & $0.607 *$ & 0.398 & 0.745 & -0.294 & 0.149 & 0.182 \\
\hline GSSG & & & 0.122 & 0.128 & 0.067 & -0.328 & $0.667^{*}$ & 0.506 & $-0.763^{*}$ & 0.051 & 0.136 & 0.643 & $-0.663^{*}$ & 0.021 & -0.038 & 0.465 & $-0.661^{*}$ & 0.033 & 0.619 \\
\hline RI GSH & & & & $0.714^{*}$ & -0.047 & -0.314 & 0.142 & 0.394 & -0.426 & 0.027 & 0.465 & $0.590 *$ & -0.255 & $0.703^{*}$ & 0.464 & $0.622^{*}$ & -0.027 & 0.126 & -0.061 \\
\hline GST & & & & & 0.010 & -0.292 & -0.067 & 0.504 & -0.502 & 0.088 & 0.250 & 0.451 & -0.280 & $0.596 *$ & $0.586^{*}$ & 0.485 & 0.094 & 0.362 & -0.322 \\
\hline SODt & & & & & & 0.646 & -0.051 & 0.098 & -0.319 & -0.115 & $0.585^{*}$ & 0.081 & 0.433 & -0.361 & 0.220 & -0.026 & 0.222 & 0.233 & -0.200 \\
\hline Mn-SOD & & & & & & & -0.320 & -0.420 & 0.319 & 0.130 & 0.114 & -0.473 & $0.648 *$ & -0.361 & 0.067 & -0.510 & 0.465 & 0.439 & -0.405 \\
\hline CAT & & & & & & & & 0.538 & -0.520 & -0.148 & 0.091 & 0.469 & -0.466 & 0.108 & -0.063 & 0.190 & -0.518 & -0.278 & $0.683^{*}$ \\
\hline TBARS & & & & & & & & & $-0.704 *$ & -0.486 & 0.172 & $0.648 *$ & $-0.598 *$ & 0.273 & -0.025 & 0.529 & -0.527 & -0.073 & 0.432 \\
\hline PC & & & & & & & & & & 0.097 & -0.270 & $-0.620 *$ & 0.504 & -0.140 & -0.200 & $-0.585^{*}$ & 0.414 & -0.031 & -0.357 \\
\hline LDH & & & & & & & & & & & -0.154 & -0.052 & -0.111 & 0.378 & 0.524 & 0.161 & 0.264 & 0.487 & -0.444 \\
\hline Lac & & & & & & & & & & & & $0.608 *$ & 0.220 & -0.023 & 0.287 & 0.232 & -0.005 & -0.086 & -0.007 \\
\hline Pyr & & & & & & & & & & & & & $-0.636^{*}$ & 0.335 & 0.13 & $0.720 *$ & $-0.609 *$ & -0.125 & 0.415 \\
\hline Lac/Pyr & & & & & & & & & & & & & & -0.383 & 0.140 & $-0.658^{*}$ & 0.763 & 0.080 & -0.518 \\
\hline Cas-3 & & & & & & & & & & & & & & & 0.571 & 0.609 & 0.113 & 0.432 & -0.251 \\
\hline CatDt & & & & & & & & & & & & & & & & 0.362 & $0.632^{*}$ & $0.629 *$ & $-0.702^{*}$ \\
\hline CatDe & & & & & & & & & & & & & & & & & -0.302 & 0.202 & 0.073 \\
\hline ALP & & & & & & & & & & & & & & & & & & 0.485 & $-0.888 *$ \\
\hline ChE & & & & & & & & & & & & & & & & & & & $-0.616^{*}$ \\
\hline
\end{tabular}


efflux of lysosomal digestion enzyme cathepsin $D$ also correlated with GSH, GST and metabolic characteristics (Table 1). Initiation of apoptosis can be triggered by a loss of cellular redox balance independently of ROS production via decreased NADPH availability for GSSG reduction (Circu \& Aw, 2008). While this study cannot provide definitive conclusions, the importance of the observed correlations between the indices of redox state is evident.

We were unable to detect specific metal toxicity in the HPP reservoir: the levels of metallothionein, which indicates toxic metal, primarily cadmium pollution (Amiard, Amiard-Triquet, Barka, Pellerin, \& Rainbow, 2006), did not show significant difference between the populations. This finding is corroborated by the similar $\mathrm{Cu}$ and $\mathrm{Zn}$ concentrations at both sites (National monitoring data: https://www.meteo.lv). A study of two Unionidae species from six lakes and watercourses of Latvia with different anthropogenic pressures also did not find any inter-site differences in the metallothionein concentrations (Purina, Barda, Rimsa, Poikane, and Jansons 2013). This finding was explained by the fact that toxic metals $(\mathrm{Cd}, \mathrm{Pb}, \mathrm{Hg}, \mathrm{Cu})$ accumulate in the deeper sediment layers, while the molluscs inhabit higher layers (Purina et al., 2013). The ChE activity was lower in the natural lake mussels. Such finding would typically indicate acute toxicity of thiocarbamates and phosphoorganic compounds (Nunes, Carvalho, \& Guilhermino, 2006; Dailianis, 2010). However, there is a debate on the meaning of this index in molluscs, i.e. low sensitivity or rapid recovery (Rickwood \& Galloway, 2004; Gagnaire, Geffard, Xuereb, Margoum, \& Garric, 2008; Bonacci, Corsi, \& Focardi, 2009). Thus, we could not definitively prove neurotoxic substances pollution in the artificial reservoir of Riga HPP.

Invasive species are known to successfully withstand polluted or degraded areas. The difficulty in evaluating the adverse impact both of field and lab exposures on zebra mussels were reported (Potet et al., $2018 a, b)$. For example, the expression of stress response genes was elevated in the mussels from a less polluted area, and negatively correlated with the level of toxic metals (Kerambrun et al., 2016). Zebra mussels from the large deep perialpine lakes Maggiore and Lugano had low accumulation of toxicants (DDx, PCBs, and $\mathrm{Hg}$ ), unlike in the fish from the same sites (Guzzella et al., 2018). Results of our study confirm that it is difficult to definitively evaluate site-related responses in the zebra mussel. Some of the markers we have detected might indicate site preferences of the invasive species adapted to a specific environment using their genetic variability, metabolic plasticity and stress response (Crooks et al., 2011; Tarnowska, DaguinThiebaut, Pain-Devin, \& Viard, 2013; Farkas et al., 2017).

To summarize, the biomarker response in zebra mussels of the Riga HPP reservoir supports the evidence of comparatively low environmental impact of such reservoirs (Atilgan \& Azapagic, 2016; Strode et al., 2017).

\section{Conclusion and Significance}

The data suggests that Riga HPP reservoir can be qualified of as overall environmentally sustainable. The indexes of the redox capacity can serve as appropriate markers of the environmental impact on this organism.

\section{References}

Aebi, H., 1974. Catalase. In: H.U. Bergmeyer (Ed.), Methods of Enzymatic Analysis (pp. 671-684). Academic Press, London, $800 \mathrm{pp}$.

Agrell, C., Larsson, P., Okla, L., Bremle, G., Johansson, N., Klavins, M., ... \& Zelechowska, A. (2001). Atmospheric and river input of PCBs, DDTs and $\mathrm{HCH}$ s to the Baltic Sea. In: F.V. Wulff, L.A. Rahm, P. Larsson (Eds), A Systems Analysis of the Baltic Sea. Ecological Studies (Analysis and Synthesis) (pp. 149-175). Springer, Berlin, Heidelberg, $457 \mathrm{pp}$.

Amiard, J.C., Amiard-Triquet, C., Barka, S., Pellerin, J., \& Rainbow, P.S., (2006). Metallothioneins in aquatic invertebrates: Their use as biomarkers. Aquatic Toxicology, 76(2), 160-202. https://doi.org/10.1016/j.aquatox.2005.08.015

Anderson, M.E. (1985). Determination of glutathione and glutathione disulfide in biological samples. Methods in Enzymology, 113, 548-555.

Atilgan, B., \& Azapagic, A. (2016). Renewable electricity in Turkey: Life cycle environmental impacts. Renewable Energy, 89, 649-657. https://doi.org/10.1016/j.renene.2015.11.082

Barda, I., Purina, I., Rimsa, E., \& Balode, M. (2014). Seasonal dynamics of biomarkers in infaunal clam Macoma balthica from the Gulf of Riga (Baltic Sea). Journal of Marine Systems, 129, 150-156. https://doi.org/10.1016/j.jmarsys.2013.05.006

Beauchamp, C., \& Fridovich, I. (1971). Superoxide dismutase: improved assay and an assay applicable to acrylamide gels. Analytical Biochemistry, 44(1), 276-287.

Benes, P., Vetvicka, V., \& Fusek, M. (2008). Cathepsin D - many functions of one aspartic protease. Critical Reviews in Oncology/Hematology, 68(1), 12-28. https://dx.doi.org/10.1016/j.critrevonc.2008.02.008

Bonacci, S., Corsi, I., \& Focardi, S. (2009). Cholinesterases in the Antarctic scallop Adamussium colbecki: characterization and sensitivity to pollutants. Ecotoxicology and Environmental Safety, 72(5), 1481-1488. https://doi.org/10.1016/j.ecoenv.2009.01.002

Bonomini, M., Dottori, S., Amoroso, A., Arduini, A., \& Sirolli, V. (2004). Increased platelet phosphatidylserine exposure and caspase activation in chronic uremia. Journal of Thrombosis and Haemostasis, 2(2), 1275-1281. https://doi.org/10.1111/j.1538-7836.2004.00837.x

Bursch, W., Karwan, A., Mayer, M., Dornetshuber, J., Frohwein, U., Schulte-Hermann, R., \& Gerner, C. (2008). Cell death and autophagy: Cytokines, drugs, and nutritional factors. Toxicology, 254(3), 147-157. https://doi.org/10.1016/j.tox.2008.07.048

Circu, M.L., \& Aw, T.Y. (2008). Glutathione and apoptosis. Free Radical Research, 42(8), 689-706. https://doi.org/10.1080/10715760802317663

Contardo-Jara, V., \& Wiegand, C. (2008). Molecular biomarkers of Dreissena polymorpha for evaluation of 
renaturation success of a formerly sewage polluted stream. Environmental Pollution, 155(1), 182-189. https://doi.org/10.1016/j.envpol.2007.10.018

Crooks, J.A., Chang, A.L., \& Ruiz, G.M. (2011). Aquatic pollution increases the relative success of invasive species. Biological Invasions, 13(1), 165-176.

https://doi.org/10.1007/s10530-010-9799-3

Dailianis, S. (2010). Environmental impact of anthropogenic activities: the use of mussels as a reliable tool for monitoring marine pollution. In: L.E. McGevin (Ed), Mussels: Anatomy, Habitat and Environmental Impact (pp. 43-72). Nova Science Publishers, Inc, 542 pp.

De Zwaan, A., \& Eertman, R.H.M. (1996). Anoxic or aerial survival of bivalves and other euryoxic invertebrates as a useful response to environmental stress - a comprehensive review Comparative Biochemistry and Physiology - Part C: Toxicology \& Pharmacology, 113(2), 299-312. https://doi.org/10.1016/0742-8413(95)021019

Dingle, J.T., Barrett, A.J., \& Weston, P.D. (1971). Cathepsin D. Characteristics of immunoinhibition and the confirmation of a role in cartilage breakdown. Biochemical Journal, 123(1), 1-13. https://doi.org/10.1042/bj1230001

Dondero, F., Dagnino, A., Jonsson, H., Caprì, F., Gastaldi, L., \& Viarengo, A. (2006). Assessing the occurrence of a stress syndrome in mussels (Mytilus edulis) using a combined biomarker/gene expression approach. Aquatic Toxicology, 78(1), S13-24. https://doi.org/10.1016/j.aquatox.2006.02.025

Ellman, G.L., Courtney, K.D., Andres, V.J., \& Featherstone, R.M. (1961). A new and rapid colorimetric determination of acetylcholinesterase activity. Biochemical Pharmacology, 7(2), 88-95. https://doi.org/10.1016/0006-2952(61)90145-9

Falfushynska, H.I., Gnatyshyna, L.L., Stoliar, O.B., DedourgeGeffard, O., \& Geffard, A. (2010). Application of multinarker approach for assessment of stress syndrome in transplanted mussels Dreissena polymorpha. Studia Biologica, 4(1), 27-38 https://doi.org/10.30970/sbi.0401.066

Faria, M., Huertas, D., Soto, D.X., Grimalt, J.O., Catalan, J., Riva, M.C., \& Barata, C. (2010). Contaminant accumulation and multi-biomarker responses in field collected zebra mussels (Dreissena polymorpha) and crayfish (Procambarus clarkii), to evaluate toxicological effects of industrial hazardous dumps in the Ebro river (NE Spain). Chemosphere, 78(3), 232-240. https://doi.org/10.1016/j.chemosphere.2009.11.003

Farkas, A., Ács, A., Vehovszky, Á., Falfusynska, H., Stoliar, O., Specziár, A., \& Győri, J. (2017). Interspecies comparison of selected pollution biomarkers in dreissenid spp. inhabiting pristine and moderately polluted sites. Science of the Total Environment, 599-600, 760-770. https://doi.org/10.1016/j.scitotenv.2017.05.033

Fu, B., Wang, Y.K., Xu, P., Yan, K., \& Li, M., (2014). Value of ecosystem hydropower service and its impact on the payment for ecosystem services. Science of the Total Environment, 472, 338-346. https://doi.org/10.1016/j.scitotenv.2013.11.015

Gagnaire, B., Geffard, O., Xuereb, B., Margoum, C., \& Garric, J. (2008). Cholinesterase activities as potential biomarkers: characterization in two freshwater snails, Potamopyrgus antipodarum (Mollusca, Hydrobiidae, Smith 1889) and
Valvata piscinalis (Mollusca, Valvatidae, Müller 1774). Chemosphere, 71(3), 553-560.

https://doi.org/10.1016/j.chemosphere.2007.09.048

Gagné, F., Blaise, C., Pellerin, J., Pelletier, E., Douville, M., Gauthier-Clerc, S., \& Viglino, L. (2003). Sex alteration in soft-shell clams (Mya arenaria) in an intertidal zone of the Saint Lawrence River (Quebec, Canada). Comparative Biochemistry and Physiology - Part C: Toxicology \& Pharmacology, 134(2), 189-198. https://doi.org/10.1016/S1532-0456(02)00248-X

Gagné, F., \& André, C. (2011). New approaches to indirect vitellogenin-like protein evaluations in aquatic oviparous and ovoviviparous organisms. Fresenius Environmental Bulletin, 20, 12-17.

Gawehn, K. (1988). D-(-)-Lactate. In: H.U. Bergmeyer (Ed.), 3rd ed, Methods of Enzymatic Analysis (pp. 588-592), $\mathrm{VCH}$ Publishers (UK) Ltd., Cambridge, UK.

Gnatyshyna, L., Falfushynska, H., Bodilovska, O., Oleynik, O., Golubev, A., \& Stoliar, O. (2012). Metallothionein and glutathione in Lymnaea stagnalis determine the specificity of responses on the effects of ionizing radiation. Radioprotection, 47(2), 231-242. https://doi.org/10.1051/radiopro/2012004

Gray, L.R., Tompkins, S.C., \& Taylor, E.B. (2014). Regulation of pyruvate metabolism and human disease. Cellular and Molecular Life Sciences, 71(14), 2577-2604. http://doi.org/10.1007/s00018-013-1539-2

Guzzella, L.M., Novati, S., Casatta, N., Guzzella, L.M., Roscioli, C., Valsecchi, L., ... Marziali, L. (2018). Spatial and temporal trends of target organic and inorganic micropollutants in Lake Maggiore and Lake Lugano (Italian-Swiss water bodies): contamination in sediments and biota. Hydrobiologia, 824(1), 271-290. https://doi.org/10.1007/s10750-017-3494-7

Habig, W.H., Pabst, M.J., \& Jakoby, W.B. (1974). Glutathione Stransferases. The first enzymatic step in mercapturic acid formation. Journal of Biological Chemistry, 249(22), 7130-7139.

HELCOM, 2018. Sources and pathways of nutrients to the Baltic Sea. Baltic Sea Environment Proceedings No. 153. Retrieved from http://www.helcom.fi/Lists/Publications/BSEP153.pdf.

Hellou, J., Ross, N.W., \& Moon, T.W. (2012). Glutathione, glutathione S-transferase, and glutathione conjugates, complementary markers of oxidative stress in aquatic biota. Environmental Science and Pollution Research, 19(6), 2007-2023. https://doi.org/10.1007/s11356-0120909-x

Hook, S.E., Gallagher, E.P., \& Batley, G.E. (2014). The role of biomarkers in the assessment of aquatic ecosystem health. Integrated Environmental Assessment and Management, 10(3), 327-341. https://doi.org/10.1002/ieam.1530

Ikkere, L.E., Perkons, I., Sire, J., Pugajeva, I., \& Bartkevics, V. (2018). Occurrence of polybrominated diphenyl ethers, perfluorinated compounds, and nonsteroidal antiinflammatory drugs in freshwater mussels from Latvia. Chemosphere, 213, 507-516. https://doi.org/10.1016/j.chemosphere.2018.09.036

Kaunda, C.S., Kimambo, C.Z., \& Nielsen, T.K. (2012). Hydropower in the Context of Sustainable Energy Supply: A Review of Technologies and Challenges. Renewable Energy, 2012, 1-15. http://dx.doi.org/10.5402/2012/730631 
Kerambrun, E., Rioult, D., Delahaut, L., Evariste, L., Pain-Devin, S., Auffret, M., ... \& David, E. (2016). Variations in gene expression levels in four European zebra mussel, Dreissena polymorpha, populations in relation to metal bioaccumulation: A field study. Ecotoxicology and Environmental Safety, 134, 53-63. https://doi.org/10.1016/j.ecoenv.2016.08.018

Kwan, K.H.M., Chan, H.M., \& de Lafontaine, Y. (2003). Metal contamination in zebra mussels (Dreissena polymorpha) along the St. Lawrence River. Environmental Monitoring and Assessment, 88(1-3), 193-219. http://dx.doi.org/10.1023/A:1025517007605

Lamarre, S.G., MacCormack, T.J., Sykes, A.V., Hall, J.R., SpeersRoesch, B., Callaghan, N.I., \& Driedzic, W.R. (2016). Metabolic rate and rates of protein turnover in fooddeprived cuttlefish, Sepia officinalis (Linnaeus 1758). American Journal of Physiology-Regulatory, Integrative and Comparative Physiology, 310(11), R1160-1168. http://dx.doi.org/10.1152/ajpregu.00459.2015

Lamprecht, W., \& Heinz, F. (1988). Pyruvate. In: H.U. Bergmeyer (Ed.), Methods of Enzymatic Analysis (pp. 570-577). VCH Publishers (UK) Ltd., Cambridge, UK.

Laznik, M., Stålnacke, P., Grimvall, A., \& Wittgren, H.B. (1999). Riverine input of nutrients to the Gulf of Riga - temporal and spatial variation. Journal of Marine Systems, 23(1-3), 11-25. https://doi.org/10.1016/S0924-7963(99)00048-2

Lebedynets, M., Sprynskyy, M., Kowalkowski, T., \& Buszewski, B. (2004). State of environment in the Dniester River Basin (West Ukraine). Environmental Science and Pollution Research, 11(4), 279-280. https://doi.org/10.1007/BF02979638

Lepom, P., Irmer, U., \& Wellmitz, J. (2012). Mercury levels and trends (1993-2009) in bream (Abramis brama L.) and zebra mussels (Dreissena polymorpha) from German surface waters. Chemosphere, 86(2), 202-211. https://doi.org/10.1016/j.chemosphere.2011.10.021

Lowry, O.H., Rosebrough, H.J., Farr, A.L., \& Randall, R.J. (1951). Protein measurement with Folin phenol reagent. Journal of Biological Chemistry, 193, 265-275.

Lushchak, V.I. (2011). Environmentally induced oxidative stress in aquatic animals. Aquatic Toxicology, 101(1), 1330. http://dx.doi.org/10.1016/j.aquatox.2010.10.006

Man, S.M., \& Kanneganti, T.-D. (2016). Regulation of lysosomal dynamics and autophagy by CTSB/cathepsin B. Autophagy, 12(12), 2504-2505. http://dx.doi.org/10.1080/15548627.2016.1239679

Matozzo, V., Gagné, F., Marin, M.G., Ricciardi, F., \& Blaise, C. (2008). Vitellogenin as a biomarker of exposure to estrogenic compounds in aquatic invertebrates: a review. Environment International, 34(4), 531-545. https://doi.org/10.1016/j.envint.2007.09.008

Menze, M.A., Fortner, G., Nag, S., \& Hand, S.C. (2010). Mechanisms of apoptosis in Crustacea: what conditions induce versus suppress cell death? Apoptosis, 15(3), 293-312. https://doi.org/10.1007/s10495-009-0443-6

Nunes, B., Carvalho, F., \& Guilhermino, L. (2006). Effects of widely used pharmaceuticals and a detergent on oxidative stress biomarkers of the crustacean Artemia parthenogenetica. Chemosphere, 62(4), 581-594. https://doi.org/10.1016/j.chemosphere.2005.06.013

Ohkawa, H., Onishi, N., \& Yagi, K. (1979). Assay for lipid peroxidation in animal tissue by thiobarbituric acid reaction. Analytical Biochemistry, 95(2), 351-358. https://doi.org/10.1016/0003-2697(79)90738-3
Portt, L., Norman, G., Clapp, C., Greenwood, M., \& Greenwood, M.T. (2011). Anti-apoptosis and cell survival: A review. Biochimica et Biophysica Acta, 1813(1), https://doi.org/10.1016/j.bbamcr.2010.10.010

Potet, M., Giambérini, L., Pain-Devin, S., Catteau, A., Pauly, D., \& Devin, S. (2018a). Impact of multiple stressors on biomarker responses in sympatric dreissenid populations. Aquatic Toxicology, 203, 140-149. https://doi.org/10.1016/j.aquatox.2018.08.007

Potet, M., Giambérini, L., Pain-Devin, S., Louis, F., Bertrand, C., \& Devin, S. (2018b). Differential tolerance to nickel between Dreissena polymorpha and Dreissena rostriformis bugensis populations. Scientific Reports, 8(1), 700. https://doi.org/10.1038/s41598-018-19228-x

Purina, I., Barda, I., Rimsa, E., Poikane, R., \& Jansons M. (2013). Concentrations of metallothionein in the bivalve molluscs Anodonta spp. and Unio spp. from Latvian lakes with different anthropogenic pressure. Proceedings of the 16th International Conference on Heavy Metals in the Environment, E3S Web of Conferences (p. 34005). https://doi.org/10.1051/e3sconf/20130134005

Putna, I., Strode, E., Bārda, I., Puriṇa, I., Rimša, E., Jansons, M., ... Strāke, S. (2014). Sediment quality of the ecoregion Engure, Gulf of Riga, assessed by using ecotoxicity tests and biomarker responses. Proceedings of the Latvian Academy of Sciences. Section B. Natural, Exact, and Applied Sciences, 68, 101-111. https://doi.org/10.2478/prolas-2014-0009

Quinn, B., Gagné, F., Costello, M., McKenzie, C., Wilson, J., \& Mothersill, C. (2004). The endocrine disrupting effect of municipal effluent on the zebra mussel (Dreissena polymorpha). Aquatic Toxicology, 66(3), 279-292. https://doi.org/10.1016/j.aquatox.2003.10.007

Rambo, C.L., Zanotelli, P., Dalegrave, D., De Nez, D., Szczepanik, J., Carazek, F., ... Magro, J.D. (2017). Hydropower reservoirs: cytotoxic and genotoxic assessment using the Allium cepa root model. Environmental Science and Pollution Research, 24(9), 8759-8768. https://doi.org/10.1007/s11356-017-8509-4

Reznick, A.Z., \& Packer, L. (1994). Oxidative damage to proteins: spectrophotometric method for carbonyl assay. Methods in Enzymology, 233, 357-363. https://doi.org/10.1016/S0076-6879(94)33041-7

Rickwood, C.J., \& Galloway, T.S. (2004). Acetylcholinesterase inhibition as a biomarker of adverse effect. A study of Mytilus edulis exposed to the priority pollutant chlorfenvinphos. Aquatic Toxicology, 67(1), 45-56. https://doi.org/10.1016/j.aquatox.2003.11.004

Riva, C., Parolini, M., Binelli, A., \& Provini, A. (2010). The case of pollution of Lake Maggiore: a twelve-year study with the bioindicator mussel Dreissena polymorpha. Water, Air, \& Soil Pollution, 210(1), 75-86. https://doi.org/10.1007/s11270-009-0225-3

Romero, A., Estévez-Calvar, N., Dios, S., Figueras, A., \& Novoa, B. (2011). New insights into the apoptotic process in mollusks: characterization of caspase genes in Mytilus galloprovincialis. PLoS One, 6(2), e17003. https://doi.org/10.1371/journal.pone.0017003

Santovito, G., Piccinni, E., Cassini, A., Irato, P., \& Albergoni, V. (2005). Antioxidant responses of the Mediterranean mussel, Mytilus galloprovincialis, to environmental variability of dissolved oxygen. Comparative Biochemistry and Physiology - Part C: Toxicology \& 
Pharmacology, 140(3-4), 321-329. https://doi.org/10.1016/j.cca.2005.02.015

Somero, G.N. (2004). Adaptation of enzymes to temperature: searching for basic "strategies. Comparative Biochemistry and Physiology - Part B: Biochemistry \& Molecular Biology, 139(3), 321-333. https://doi.org/10.1016/j.cbpc.2004.05.003

Stålnacke, P., Tamminen, T., Vagstad, N., Wassmann, P., Loigu, E., \& Jansons, V. (1999). Nutrient runoff and transfer from land and rivers to the Gulf of Riga. Hydrobiologia, 410, 103-110. https://doi.org/10.1023/A:1003736620843

Strode, E., Jansons, M., Purina, I., Balode, M., \& Berezina, N.A. (2017). Sediment quality assessment using survival and embryo malformation tests in amphipod crustaceans: The Gulf of Riga, Baltic Sea AS case study. Journal of Marine Systems, 172, 93-103. https://doi.org/10.1016/j.jmarsys.2017.03.010

Tarnowska, K., Daguin-Thiebaut, C., Pain-Devin, S., \& Viard, F. (2013). Nuclear and mitochondrial genetic variability of an old invader, Dreissena polymorpha (Bivalvia), in French river basins. Biological Invasions, 15(11), 25472561. http://dx.doi.org/10.1007/s10530-013-0472-5

Viarengo, A., Lowe, D., Bolognesi, C., Fabbri, E., \& Koehler, A. (2007). The use of biomarkers in biomonitoring: a 2-tier approach assessing the level of pollutant-induced stress syndrome in sentinel organisms. Comparative Biochemistry and Physiology - Part C: Toxicology \& Pharmacology, 146(3), 281-300. https://doi.org/10.1016/j.cbpc.2007.04.011
Viarengo, A., Ponzano, E., Dondero, F., \& Fabbri, R. (1997). A simple spectrophotometric method for metallothionein evaluation in marine organisms: an application to Mediterranean and Antarctic Molluscs. Marine Environmental Research, 44(1), 69-84. https://doi.org/10.1016/S0141-1136(96)00103-1

Vuori, K., Kiljunen, M., Kanerva, M., Koljonen, M. L., \& Nikinmaa, M. (2012). Stock-specific variation of trophic position, diet and environmental stress markers in Atlantic salmon Salmo salar during feeding migrations in the Baltic Sea. Journal of Fish Biology, 81(6), 1815-1833. https://doi.org/10.1111/j.1095-8649.2012.03386.x

Wang, Q., Yuan, Z., Wu, H., Liu, F., \& Zhao, J. (2013). Molecular characterization of a manganese superoxide dismutase and copper/zinc superoxide dismutase from the mussel Mytilus galloprovincialis. Fish and Shellfish Immunology, 34(5),

1345-1351. https://doi.org/10.1016/j.fsi.2013.01.011

Warner, R.F. (2012). Environmental impacts of hydroelectric power and other anthropogenic developments on the hydromorphology and ecology of the Durance channel and the Etang de Berre, southeast France. Journal of Environmental Management, 104, 35-50. https://doi.org/10.1016/j.jenvman.2012.03.011

Zhu, H.-N., Yuan, X.-Z., Zeng, G.-M., Jiang, M., Liang, J., Zhang, C., \& Jiang, H.-W. (2012). Ecological risk assessment of heavy metals in sediments of Xiawan Port based on modified potential ecological risk index. Transactions of Nonferrous Metals Society of China, 22(6), 1470-1477. https://doi.org/10.1016/S1003-6326(11)61343-5 